\title{
Kontrola jakości procesu zgrzewania rezystancyjnego doczołowego iskrowego
}

\author{
Quality control in flash butt resistance welding
}

\section{Streszczenie}

W artykule opisano działanie systemu kontroli i oceny jakości procesu zgrzewania doczołowego iskrowego na przykładzie technologii zgrzewania prętów zbrojeniowych wykorzystywanych w budownictwie. System pomiarowy o nazwie LogWeld dokonuje pomiaru podstawowych wielkości procesu tj. prądu i napięcia zgrzewania, siły docisku i przemieszczenia elektrod (skrócenie elementów) w czasie zgrzewania. Kontrola procesu obejmuje kilkanaście wielkości charakterystycznych, z których każda ma określony wpływ na przebieg procesu w tym na jakość połączeń zgrzewanych. System został wdrożony w jednym z zakładów przemysłowych w Polsce. Rozwiązanie w postaci "Sposób kontroli jakości procesu zgrzewania rezystancyjnego doczołowego iskrowego" zostało zgłoszone do Urzędu Patentowego i otrzymało nr P.410708.

Słowa kluczowe: zgrzewanie rezystancyjne doczołowe iskrowe, kontrola jakości procesu zgrzewania, system kontroli jakości

\section{Abstract}

The article presents the operation of a system for controlling and assessing quality in flash butt resistance welding illustrated with an example of a technology for welding reinforcement bars used in building engineering. A measurement system named LogWeld measures basic process parameters, i.e. welding current and voltage as well as force and movements of electrodes during welding (element length reduction). The control of a welding process includes more than ten characteristic quantities, each of which has a specific influence on the course of a process and on the quality of welded joints. The system has been successfully implemented in one of industrial plants in Poland. The solution entitled Method for Controlling Quality in Flash Butt Resistance Welding has been filed at the Polish Patent Office and numbered P.410708.

Keywords: flash butt resistance welding, welding process quality control, quality control system

\section{Wstęp}

Jak każdy proces spajania, w tym również zgrzewanie rezystancyjne jest procesem specjalnym, który wymaga dodatkowych działań związanych z kontrolą (parametrów) w czasie procesu technologicznego dla zapewnienia odpowiedniej jakości wykonywanych złączy. Zgrzewarki doczołowo iskrowe powinny być wyposażone w układy sterowania, które są w stanie precyzyjnie i powtarzalnie sterować wartością i czasem przepływu prądu zgrzewania, prędkością zgrzewania (przesuwem elementów zgrzewanych) i zagwarantować wymaganą wartość siły docisku oraz jej stabilność. Dla tak określonych warunków, proces zgrzewania powinien być powtarzalny.

Istnieje jednak, jak w każdym procesie technologicznym, wiele zależnych i niezależnych (przypadkowych) czynników mających niekorzystny wpływ na przebieg, w tym przypadku na przebieg procesu zgrzewania i tym samym na wynik końcowy jakim jest jakość wykonywanych połączeń. Dlatego dla zapewnienia odpowiedniej jakości i powtarzalności procesu konieczne jest precyzyjne (dokładne) i powtarzalne sterowanie $\mathrm{w} / \mathrm{w}$ parametrami procesu ale również ich monitorowanie, kontrola, analiza i ocena.

Analiza wspomnianych parametrów pozwala na ocenę przebiegu procesu i stwierdzenie czy proces jest powtarzalny w przyjętym zakresie dopuszczalnych (akceptowalnych) zmian przyjętych wartości granicznych. Jeśli tak, to z dużym prawdopodobieństwem jakość procesu również będzie powtarzalna i zapewniona będzie odpowiednia jakość wykonywanych złączy. Jeśli nie, istnieje przypuszczenie, że zmiany procesu mogą mieć negatywny wpływ na jakość wykonywanych złączy. W pierwszym przypadku otrzymujemy informację z systemu kontroli potwierdzającą wymaganą jakość, co pozwala na kontynuację procesu produkcyjnego. W drugim przypadku, otrzymujemy informację, że wystąpiła sytuacja awaryjna mogącą negatywnie wpływać na jakość produkcji. Informacja taka pozwala na wyeliminowanie elementu z dalszego cyklu produkcyjnego w najwłaściwszym momencie tj. po wykryciu sytuacji awaryjnej. Możliwe jest również wtedy sprawdzenie przyczyny zakłócenia procesu (zgrzewania) i dokonania stosownych czynności naprawczych przywracających pełną zdolność produkcyjną i sprawność maszyny (zgrzewarki).

Coraz częściej dla złączy odpowiedzialnych, których wadliwe wykonanie i tym samym brak odpowiedniej jakości może być przyczyną strat materialnych lub stanowić może

Dr inż. Zygmunt Mikno, mgr inż. Tadeusz Szebeszczyk, Kazimierz Czylok - Instytut Spawalnictwa, Gliwice. 
zagrożenie dla zdrowia i życia, wymaga się odpowiedniej kontroli procesu. Najlepsza jest oczywiście metoda nieniszcząca, i taka która jest wstanie objąć kontrolą 100\% produkowanych wyrobów (produkcji).

Technologia zgrzewania iskrowego wykorzystywana jest w odpowiedzialnych i wymagających dziedzinach gospodarki jakim jest budownictwo czy kolejnictwo. W budownictwie stosowane jest np. do zgrzewania prętów zbrojeniowych do łączenia stropów budynków i balkonów bez przewiązki betonowej. W kolejnictwie zgrzewanie iskrowe wykorzystywane jest do łączenia również odpowiedzialnych elementów tj. szyn kolejowych [1].

\section{Stan aktualny}

Z uwagi na zapewnienie odpowiedniej jakości procesu oraz wymagań systemów jakości dotyczących procedur kontroli i monitorowania procesów technologicznych, firmy produkcyjne poszukują odpowiednich metod i specjalistycznej aparatury/urządzeń do kontroli procesu. Wspomniane zgrzewanie szyn kolejowych [1] prowadzone między innymi metodą zgrzewania doczołowego iskrowego, z uwagi na odpowiedzialność wykonywanych złączy i wymogi bezpieczeństwa jest prowadzone $z$ wykorzystaniem rozbudowanych systemów monitorowania procesu zgrzewania.

Główne parametry mierzone to prąd i napięcie zgrzewania, siła docisku i przemieszczenie elektrod. Zgrzewarki wraz z głowicami pomiarowymi umożliwiają prowadzenie procesu zgrzewania w warunkach stacjonarnych (zakład przemysłowy) ale mogą być urządzeniami mobilnymi montowanymi na samochodach ciężarowych lub pojazdach szynowych, a próby zgrzewania są przeprowadzane w warunkach polowych.

Autorzy publikacji [1] dokonali przeglądu dostępnych i stosowanych w kraju urządzeń do zgrzewania szyn kolejowych wraz tzw. głowicami pomiarowymi (układami/systemami pomiarowymi):

- zgrzewarka firmy Schlatter z układem sterowania i monitorowania procesu typu AMS 100. Monitorowane parametry to: prąd zgrzewania, siła (bezpośrednio) i przemieszczenie elektrod;
- zgrzewarka Vaia Car (Ukraina) z głowicą K 355 A1. Monitorowane parametry to: prąd zgrzewania, siła docisku (pośrednio przez ciśnienie) i przemieszczenie elektrod;

- zgrzewarka firmy Holland Company L. P. (głowica K 355 H). Monitorowane parametry to: prąd zgrzewania, siła (bezpośrednio) i przemieszczenie elektrod;

- zgrzewarka KCM 005 z głowicą K-922-1. Monitorowane parametry to: prąd i napięcie transformatora, siła docisku (pośrednio przez ciśnienie) i przemieszczenie elektrod.

W artykule autorzy dokonali przeglądu dostępnych i stosowanych w kraju urządzeń do zgrzewania pod kątem możliwości rejestracji parametrów. Głównym wnioskiem była konieczność monitorowania parametrów co powinno zapewnić kontrolę procesu i przez to jakość wykonywanych połączeń. W podsumowaniu brak jednak opinii autorów na temat zmian parametrów zgrzewania i tym samym ich wpływu na przebieg procesu oraz jakość wykonywanych złączy.

Brak jest również jednoznacznego stwierdzenia czy mierzone parametry prąd i napięcia są parametrami pierwotnymi czy wtórnymi obwodu transformatora. Należy mieć świadomość, że prąd i napięcie mierzone w obwodzie wtórnym to prąd i napięci zgrzewania. Jednak transformatory zgrzewalnicze pracują blisko nasycenia co prowadzić może do złej interpretacji parametrów zgrzewania w przypadku analizy prądu i napięcia po stronie pierwotnej transformatora.

W niektórych rozwiązaniach mierzony jest tylko prąd zgrzewania bez napięcia. Brak pomiaru tego kluczowego parametru nie pozwala na określenie energii w czasie procesu, co jest słabą stroną takiego rozwiązania.

\section{Technologia zgrzewania doczołowego iskrowego}

Podstawowe parametry procesu zgrzewania doczołowego iskrowego to [2,3]:

- prędkość w fazie wyiskrzania i spęczania,

- naddatek na wyiskrzanie i spęczanie $\Delta S$ (rys. 1),

- wartość prądu w fazie wyiskrzania i spęczania,

- siła docisku w fazie wyiskrzania i spęczania,

- długość wysunięcia elementów zgrzewanych ze szczęk Lz (rys. 1).

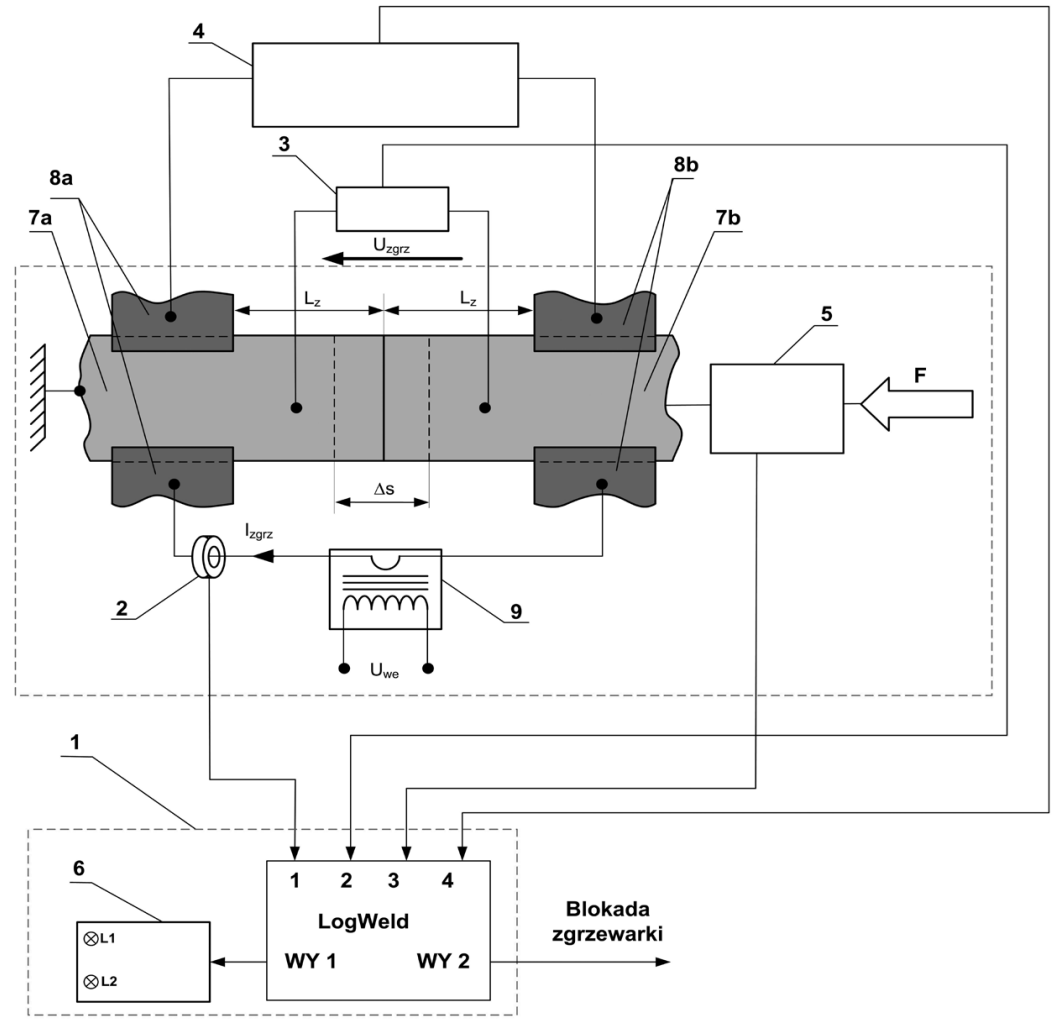

Rys. 1. Schemat połączeń systemu pomiarowego LogWeld i elementów zgrzewarki doczołowo iskrowej: 1) system pomiarowy LogWeld, 2) czujnik pomiaru prądu zgrzewania, 3) czujnik pomiaru napięcia zgrzewania, 4) czujnik pomiaru skrócenia elementów zgrzewanych, 5) czujnik pomiaru siły docisku, 6) sygnalizatory optyczne (potwierdzenia poprawnej technologii zgrzewania i wykrycia sytuacji awaryjnej), 7a) element zgrzewany nieruchomy, 7b) element zgrzewany ruchomy, 8a) elektroda nieruchoma, 8b) elektroda ruchoma, 9) transformator zgrzewarki, $\Delta \mathrm{s}$ - całkowity naddatek na skrócenie materiałów zgrzewanych, $L z$ - długość wysunięcia elementów zgrzewanych ze szczęk

Fig. 1. Connection diagram of a LogWeld measurement system and of a flash butt resistance welding machine: 1) LogWeld measurement system, 2) welding current sensor, 3) welding voltage sensor, 4) element length reduction sensor, 5) force sensor, 6) signal lights (confirmation of a proper welding technology and of detecting an imperfection), $7 a)$ immobile welded element, $7 b$ ) mobile welded element, 8a) immobile electrode, 8b) mobile electrode, 9) welding machine transformer, $\Delta s$ - total allowance for welded element length reduction, $L z$ - welded element exposed length (from jaws) 
Istotnym parametrem, z punktu widzenia powtarzalności i prawidłowego przebiegu procesu jest również kąt początkowego styku elementów zgrzewanych dla zainicjowania procesu wyiskrzania. W praktyce stosuje się, w przypadku mniejszych przekrojów porzecznych, ukosowanie jednego z elementów zgrzewanych, a przy dużych przekrojach (i płaskich powierzchniach czołowych) elementy na początku dosuwa się do siebie pod pewnym kątem zastępującym w ten sposób kosztowną i czasochłonną operacją ukosowania elementów.

Na rysunku 1 przedstawiono schemat połączeń systemu pomiarowego LogWeld z elementami składowymi zgrzewarki i czujnikami pomiarowymi.

Zgrzewanie iskrowe charakteryzuje kilka istotnych zalet tj.: - możliwość uzyskania wytrzymałości na rozciąganie połączenia zgrzewanego zbliżonego do wytrzymałości materiału rodzimego,

- naturalne usunięcie poza złącze wszelkich zabrudzeń w fazie wyiskrzania,

- brak konieczności starannego przygotowania powierzchni czołowych elementów zgrzewanych.

Technologia zgrzewania doczołowego iskrowego może przybierać bardzo złożony charakter i składać się z kilku przedziałów takich jak : wyiskrzanie wstępne, podgrzewanie wstępne, wyiskrzanie właściwe, spęczanie, obróbka cieplna [2]. Dla uproszczenia w publikacji rozpatrywano tylko dwa przedziały tj. fazę wyiskrzania właściwego i fazę spęczania.

\section{System pomiarowy LogWeld}

Doświadczenia Instytutu Spawalnictwa w zakresie kontroli procesu zgrzewania rezystancyjnego i oceny jakości wskazują na konieczność pomiaru takich parametrów jak: prąd i napięcia po stronie wtórnej transformatora oraz siły

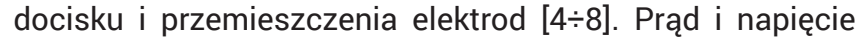
wtórne można określić mianem prądu i napięcia zgrzewania. W takim przypadku możemy mówić o energii i to wprost o energii dostarczonej do zgrzeiny. Energia elektryczna jest tożsama z energią cieplną, która wpływa bezpośrednio na nagrzanie i stapianie materiałów zgrzewanych. Kontrola tego parametru jest jednym z kluczowych elementów zapewnienia jakości.

Pomiar prądu i napięcia zgrzewania (prąd i napięcie wtórne transformatora) pozwalają na wyznaczenie (wyliczenie) dodatkowych wielkości pochodnych, również bardzo ważnych z punktu widzenia oceny poprawności procesu. Parametrami tymi są przebieg mocy chwilowej, przebieg energii i rezystancji zastępczej statycznej. Charakter przebiegu tych wielkości i osiągane wartości są bardzo przydatne w czasie kontroli i analizie procesu zgrzewania.

Wyniki w postaci zarejestrowanych parametrów, prądu i napięcia zgrzewania oraz siły docisku i przemieszczenia elektrod (które jest tożsame ze skróceniem materiałów w czasie zgrzewania) dla dwóch przypadków przedstawiono na rysunkach 2 i 3, które odpowiednio przedstawiają poprawny i niepoprawny przebieg proces zgrzewania.

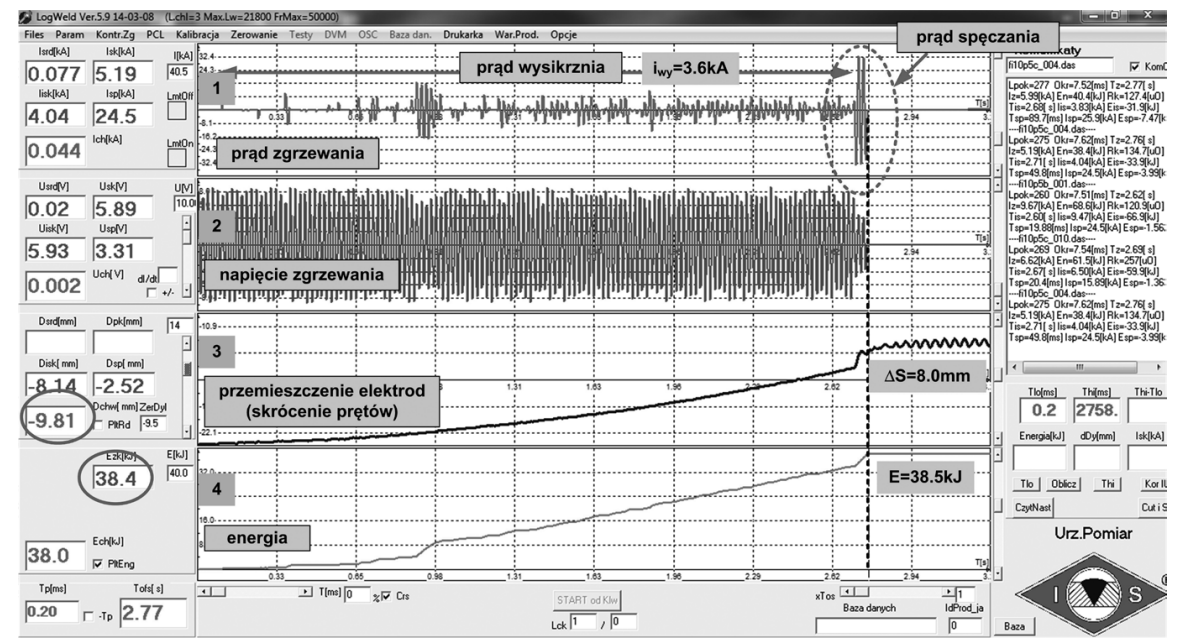

Rys. 2. Ekran monitora przyrządu pomiarowego LogWeld z rejestracją prądu i napięcia zgrzewania, przemieszczenia elektrod (skrócenia prętów) i energii (dostarczona do zgrzeiny) dla poprawnego procesu zgrzewania (warunki nominalne)

Fig. 2. LogWeld measurement device monitor display: recording of welding current and voltage, recording of electrode movement (bar length reduction) and energy (energy supplied to a weld) for properly performed welding

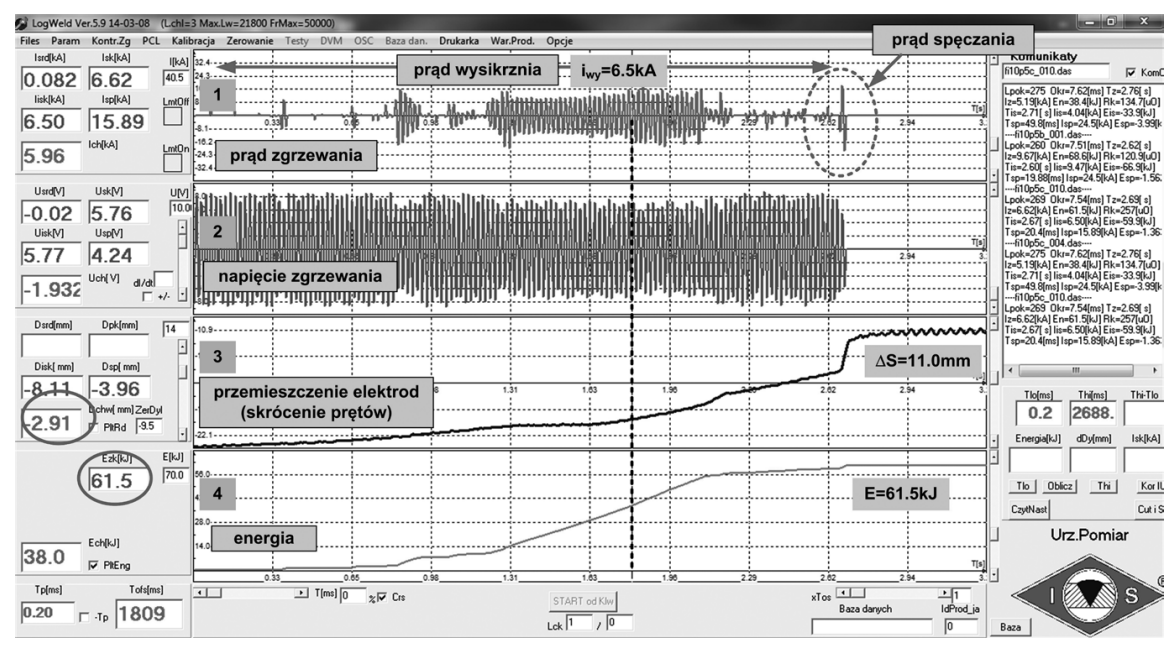

Rys. 3. Ekran monitora przyrządu pomiarowego LogWeld z rejestracją prądu i napięcia zgrzewania, przemieszczenia elektrod (skrócenia prętów) i energii (dostarczona do zgrzeiny) dla niepoprawnego procesu zgrzewania (wprowadzone zakłócenie w postaci żużla).

Fig. 3. LogWeld measurement device monitor display: recording of welding current and voltage, recording of electrode movement (bar length reduction) and energy (energy supplied to a weld) for improperly performed welding. 
Różnice w przedstawionych dwóch różnych procesach zgrzewania są widoczne w charakterze przebiegu i wartości prądu wyiskrzania (okno $\mathrm{nr} 1$ : rys. $2, \mathrm{i}_{w y}=3.6 \mathrm{kA}$ i rys. 3 , $\mathrm{i}_{\mathrm{wy}}=6.5 \mathrm{kA}$ ), ale również energii dostarczanej do zgrzeiny (okno $\mathrm{nr}$ 4: rys. 2, $\mathrm{E}=38.5 \mathrm{~kJ}$ i rys. $3, \mathrm{E}=61.6 \mathrm{~kJ}$ ) oraz przemieszczeniu elektrod (okno $\mathrm{nr} 3$ : rys. $2, \Delta \mathrm{S}=8.0 \mathrm{~mm}$ i rys. 3 , $\Delta \mathrm{S}=11.0 \mathrm{~mm}$ ).

Uzyskane wyniki dla prezentowanych przypadków w dwóch próbach przedstawionych na rysunkach $2 \mathrm{i} 3$ wykazują duże różnice. Wzrosła zarówno energia zgrzewania o ok. $60 \%$, prąd wyiskrzania o ok. $80 \%$ i wzrosło skrócenie elementów zgrzewanych (prętów o ok. 40\%). Wskazuje to na możliwość zarówno pomiaru parametrów procesu jak i wykrywania sytuacji awaryjnych, a przez to możliwość oceny jakości.

Paradoksem wynikającym z porównania przebiegów z rysunkach 2 i 3 jest to, że wzrost energii zgrzewania wcale nie powoduje poprawy jakości i wzrostu wytrzymałości połączenia. Efekt jest wręcz odwrotny. Energia jest większa ale tylko $w$ fazie wyiskrzania. Jest to energia nieużyteczna (energia strat). Powoduje ona nadmierne nagrzanie $\mathrm{w}$ obszarze zgrzewania co skutkuje większym zgniotem elementów zgrzewanych. Przypadek z rysunku 3 jest zaliczany jako niepoprawny proces zgrzewania.

Opracowany i wdrożony system LogWeld dla zgrzewania iskrowego prętów wylicza i kontroluje następujące wielkości:

- wartość prądu spęczania ( $I_{s p}$, kolumna 3 tabl. I),

- rezystancję zgrzeiny (złącza) ( $\mathrm{R}_{\mathrm{zg}}$ kolumna 4 tabl. I),

- energię dostarczoną do złącza zgrzewanego $\left(E_{z g}\right.$, kolumna 5 tabl. I),

- czas spęczania ( $T_{\text {sp }}$, kolumna 6 tabl. I),

- siłę spęczania ( $F_{\text {sp }}$, kolumna 7 tabl. I),

- skrócenie prętów (przemieszczenie elektrod) ( $D_{z g}$, kolumna 8 tabl. I),

- wartość prądu wyiskrzania (I wi, kolumna 9 tabl. I).

W kolumnie 10 tablicy I zaznaczono wyniki oceny kontroli procesu zgrzewania dla dwóch systemów kontroli jakości. Dla systemu dotychczasowego zainstalowanego na zgrzewarce $\mathrm{z}$ oznaczeniem $\mathrm{H}$ (firma w której zainstalowano system, lewa strona kolumny 10) i nowego systemu LogWeld wdrożonego przez Instytut Spawalnictwa z oznaczeniem IS (prawa strona kolumny 10). Zapis w kolumnie 10 „Err” oznacza wykrycie sytuacji awaryjnej, natomiast "OK” brak wykrycia sytuacji awaryjnej według przyjętych kryteriów oceny i oznacza tym samym poprawność procesu zgrzewania przez dotychczasowy system.

Przygotowanie systemu pomiarowego LogWeld do pracy polega na rejestracji odpowiedniej liczby przebiegów (ok. 100-200) określonych jako poprawne (Tabela I, wiersz 1). System automatycznie określa wartości graniczne granicy górnej i dolnej (tabl. l, wiersz 2) dla wyznaczonych parametrów podlegających kontroli w czasie procesu zgrzewania

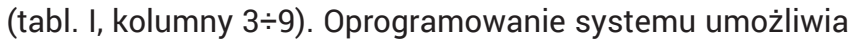
określenie wartości odchyleń średnio kwadratowych a granica górna i dolna wyznaczana jest w tym przypadku automatycznie. Możliwe jest również ręczne ustawienie wartości granicznych, co pozwala na modyfikowanie zakresu dopuszczalnych zmian danego parametru uwzględniając potrzeby technologii i doświadczenie technologa.

Zamieszczone wyniki w tablicy I w wierszach $3 \div 5$ przedstawiają wykrycie sytuacji awaryjnej wraz opisem przyczyny jej powstania (kolumna 11). Szczegóły zostaną omówione w kolejnym punkcie pt. Weryfikacja skuteczności oceny systemu pomiarowego

\section{Weryfikacja skuteczności oceny systemu pomiarowego}

System LogWeld do kontroli i oceny jakości procesu zgrzewania iskrowego został wdrożony w jednym z polskich zakładów produkcyjnych. Elementy zgrzewane dla których wdrażano system pomiarowy LogWeld to pręty zbrojeniowe: stal zbrojeniowa (średnica ok. $12 \mathrm{~mm}$ ) i stal nierdzewna (średnica ok.10 mm). Informacje dotyczące zarówno nazwy producenta jak i dodatkowych szczegółów dotyczących produkcji (zgrzewanych materiałów) zostały zastrzeżone klauzurą poufności przez partnera przemysłowego.

Tablica I. Wyniki pomiarów wielkości charakterystycznych procesu zgrzewania iskrowego Table I. Measurement results of flash welding process characteristic quantities

\begin{tabular}{|c|c|c|c|c|c|c|c|c|c|c|c|}
\hline 1 & 2 & 3 & 4 & 5 & 6 & 7 & 8 & 9 & \multicolumn{2}{|c|}{10} & 11 \\
\hline \multirow{2}{*}{ Ip. } & \multirow{2}{*}{ Nazwa serii } & \multirow{2}{*}{$I_{s p}$} & \multirow{2}{*}{$\mathrm{R}_{\mathrm{zg}}$} & \multirow{2}{*}{$E_{z g}$} & \multirow{2}{*}{$\mathrm{T}_{\mathrm{sp}}$} & \multirow{2}{*}{$\mathrm{F}_{\mathrm{sp}}$} & \multirow{2}{*}{$D_{z g}$} & \multirow{2}{*}{$I_{w i}$} & \multicolumn{2}{|c|}{ ocena } & \multirow{2}{*}{ Uwagi } \\
\hline & & & & & & & & & $\mathrm{H}$ & IS & \\
\hline 1 & $\begin{array}{l}\min 200 \text { zgrzein } \\
\text { (średnia) }\end{array}$ & 24.6 & 159 & 37.7 & 60 & 1903 & 10.8 & 3.88 & & & Średnie wartości \\
\hline 2 & $\begin{array}{l}\text { Granica górna } \\
\text { Granica dolna }\end{array}$ & $\begin{array}{l}26.0^{d)} \\
23.2^{d)}\end{array}$ & $\begin{array}{l}191^{\mathrm{d})} \\
128^{\mathrm{d})}\end{array}$ & $\begin{array}{l}41.9^{d)} \\
33.5^{d)}\end{array}$ & $\begin{array}{l}100^{d)} \\
20^{d)}\end{array}$ & $\begin{array}{l}1911^{d)} \\
1896^{d)}\end{array}$ & $\begin{array}{l}11.5^{d)} \\
10.0^{d)}\end{array}$ & $\begin{array}{l}4.2^{d)} \\
3.55^{d)}\end{array}$ & & & $\begin{array}{l}\text { ustalenie granicy górnej } \\
\text { i dolnej dla } \pm 3 s^{d)}\end{array}$ \\
\hline 3 & nr. S3_12 & $19.0^{a)}$ & & $57.0^{\mathrm{a})}$ & & & $12.2^{\mathrm{a})}$ & $6.4^{\mathrm{a})}$ & $\mathrm{OK}^{\mathrm{b})}$ & $\mathrm{Err}^{\mathrm{a})}$ & Przepalenie $^{c)}$ \\
\hline 4 & nr. S5_50 & $17.7^{\mathrm{a})}$ & & $58.6^{a)}$ & & & $15.6^{\mathrm{b})}$ & $5.7^{\mathrm{a})}$ & $\mathrm{Err}^{\mathrm{a}}{ }^{2}$ & $\mathrm{Err}^{\mathrm{a})}$ & $\begin{array}{l}\text { Brak zgrzania: } \\
\text { - prąd spęczania mały }{ }^{c)} \\
\text { - energia dużac) } \\
\text { - prąd wyiskrzania dużyc) }\end{array}$ \\
\hline 5 & nr. S5_172 & & & $49.5^{\mathrm{a})}$ & & & & $6.0^{a)}$ & $\mathrm{OK}^{\mathrm{b})}$ & $\mathrm{Err}^{\mathrm{a})}$ & $\begin{array}{c}\text { Przepalenie złącza } \\
\text { zgrzewanegoc) }\end{array}$ \\
\hline \multicolumn{12}{|c|}{$\begin{array}{l}\text { a) - pozytywna ocena systemu (LogWeld - IS) } \\
\text { b) - wartości parametrów poza granicami, brak } \\
\text { c) - opis sytuacji awaryjnej }\end{array}$} \\
\hline
\end{tabular}


Na rysunku 4 przedstawiono zgrzewarkę iskrową do zgrzewania prętów zbrojeniowych.

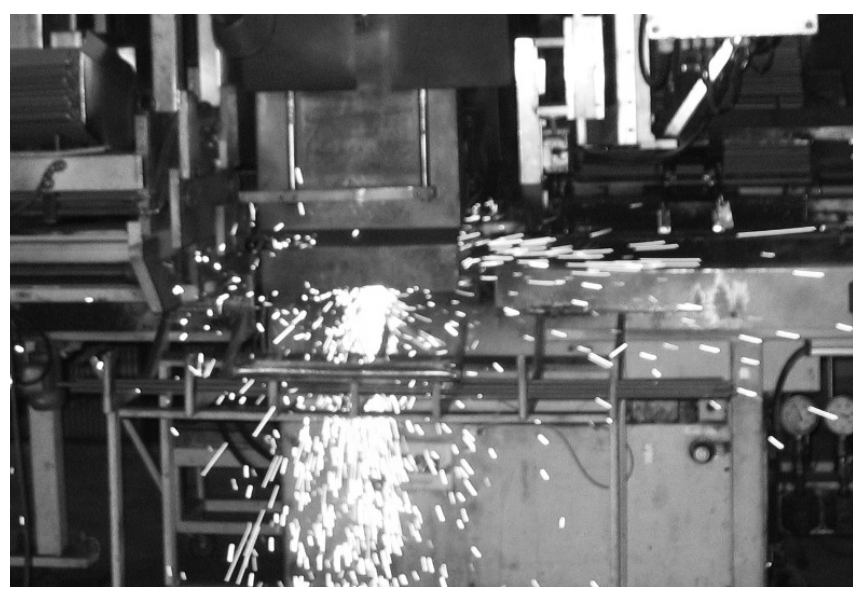

Rys. 4. Zgrzewarka rezystancyjna doczołowo iskrowa w czasie procesu zgrzewania

Fig. 4. Flash butt resistance welding machine in operation

Na rysunku 5 przedstawiono przykładowe zdjęcia złączy zgrzewanych dla wyników przestawionych w tablicy I (wiersze $3 \div 5$ ). Przypadki te scharakteryzować można następująco:

- przepalenie elementów (prętów) zgrzewanych (rysunek 5a, tablica I - wiersz 3, próbka $\mathrm{nr} 12$ ),

- brak zgrzania: prąd spęczania mały, energia duża, prąd wyiskrzania duży (rysunek 5b, tablica I - wiersz 4, próbka nr 50),

- przepalenie złącza zgrzewanego (rysunek 5c, tablica I - wiersz 5, próbka nr 172).
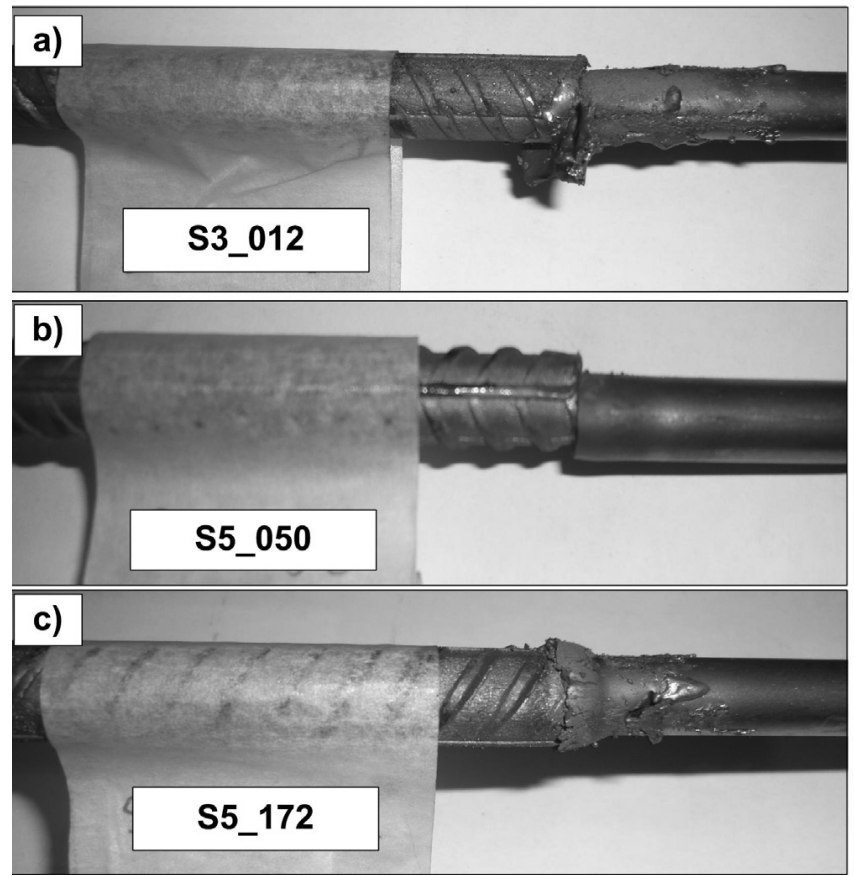

Rys. 5. Złącza zgrzewane dla wykrytej sytuacji awaryjnej: a) przepalenie złącza zgrzewanego (nazwa zbioru: S3_012, 2014.12.15), b) brak zgrzania: prąd spęczania mały, energia duża, prąd wyiskrzania duży (nazwa zbioru: S5_050, 2014.12.15), c) przepalenie złącza zgrzewanego (nazwa zbioru: S5_172, 2014.12.15).

Fig. 5. Welded joints with detected imperfections: a) welded joint burn-through, b) lack of joint: low upsetting current, high energy, high flashing current, c)welded joint burn-through.

System LogWeld działa dwustanowo. W przypadku poprawnej technologii zgrzewania (rys. 6b) uaktywniany jest zielony sygnalizator. W przypadku sytuacji awaryjnej uaktywniany jest czerwony sygnalizator (rys. 6a) i dodatkowo sygnał blokady zgrzewarki (rys. 1). Skuteczność oceny zależy od: rodzaju kontrolowanego parametru, wartości nastaw granicznych dla poszczególnych kontrolowanych parametrów. Wybór parametru polegającego kontroli i wartość nastaw zależą od wiedzy i doświadczenia technologa.
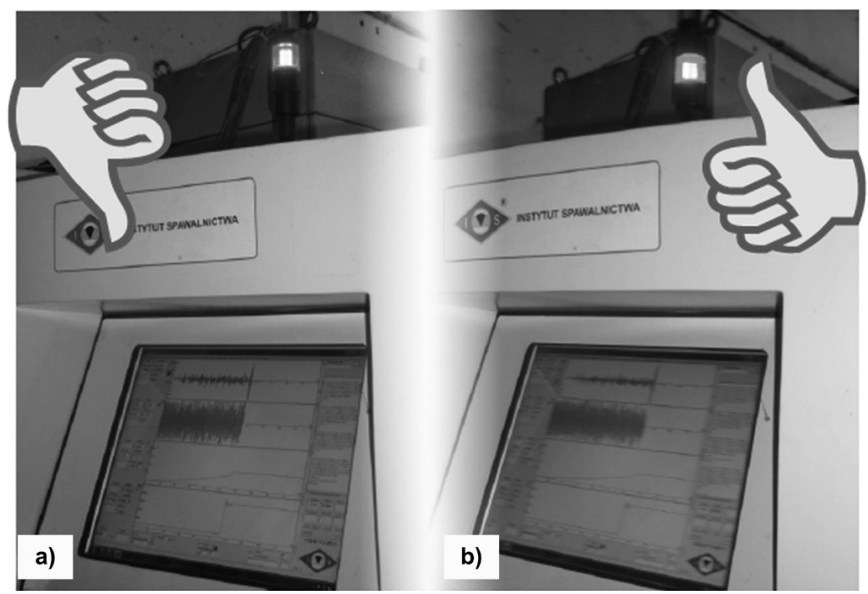

Rys. 6. System LogWeld w czasie pracy, tj. rejestracji parametrów i oceny jakości dla: a) niepoprawnie wykonanej zgrzeiny (wykryta sytuacja awaryjna), b) poprawnie wykonanej zgrzeiny.

Fig. 6. Welded joints with detected imperfections: a) welded joint burn-through, b) lack of joint: low upsetting current, high energy, high flashing current, c) welded joint burn-through.

\section{Dyskusja wyników}

Dyskusję wyników najlepiej przeprowadzić w odniesieniu do zarejestrowanych zbiorczych przebiegów wielkości charakterystycznych procesu zgrzewania iskrowego przedstawionych na rysunku 7 . Przedstawione przebiegi to: prąd zgrzewania, napięcie zgrzewania, skrócenie elementów, energia i siła docisku. Wielkości zostały zarejestrowane dla normalnego cyklu produkcyjnego. Zarejestrowane i przedstawione przypadki świadczą jednak o możliwości wystąpienia dużych rozrzutów parametrów. Na rysunku 7 zamieszczono również dwa przypadki z tablicy l (wiersze 4 i 5).

Dla poprawnej analizy przebiegów należy nadmienić, że czas fazy wyiskrzania i fazy spęczania został wyznaczony dla przebiegu prądu i napięcia zgrzewania dla technologicznej próby zgrzewania S5_039. W pozostałych zarejestrowanych próbach czasy fazy wyiskrzania i fazy spęczania różnią się nieznacznie pomiędzy sobą. Różnice wynikają z czasu początku rejestracji (wyzwalania) prądu wyiskrzania, który może być różny dla każdego cyklu zgrzewania.

Analiza wyników szczególnie w przypadku nałożenia przebiegów (rys. 7) wskazuje, że największe różnice są widoczne dla przebiegu energii i skrócenia elementów zgrzewanych (prętów). Wyraźne różnice w wartości skrócenia są widoczne $w$ fazie spęczania i bezpośrednio po jej zakończeniu. Wpływ na wartość skrócenia elementów zgrzewanych w fazie spęczania, szczególnie na początku ma zarówno energia nagrzewania w czasie fazy wyiskrzania (dokładnie wartość skuteczna prądu wyiskrzania), ale również wartość siły docisku i szybkość jej odziaływania czyli tzw. przyłożenia po zaniku fazy wyiskrzania.

Przebiegi siły docisku i wartości nominalne dla zgrzewarki iskrowej w której wdrożono system LogWeld są powtarzalne i stałe. Wydaje się zatem, że nie mają istotniejszego wpływu na przebieg procesu w tym na jego jakość w analizowanych na rysunku 7 przypadkach. 

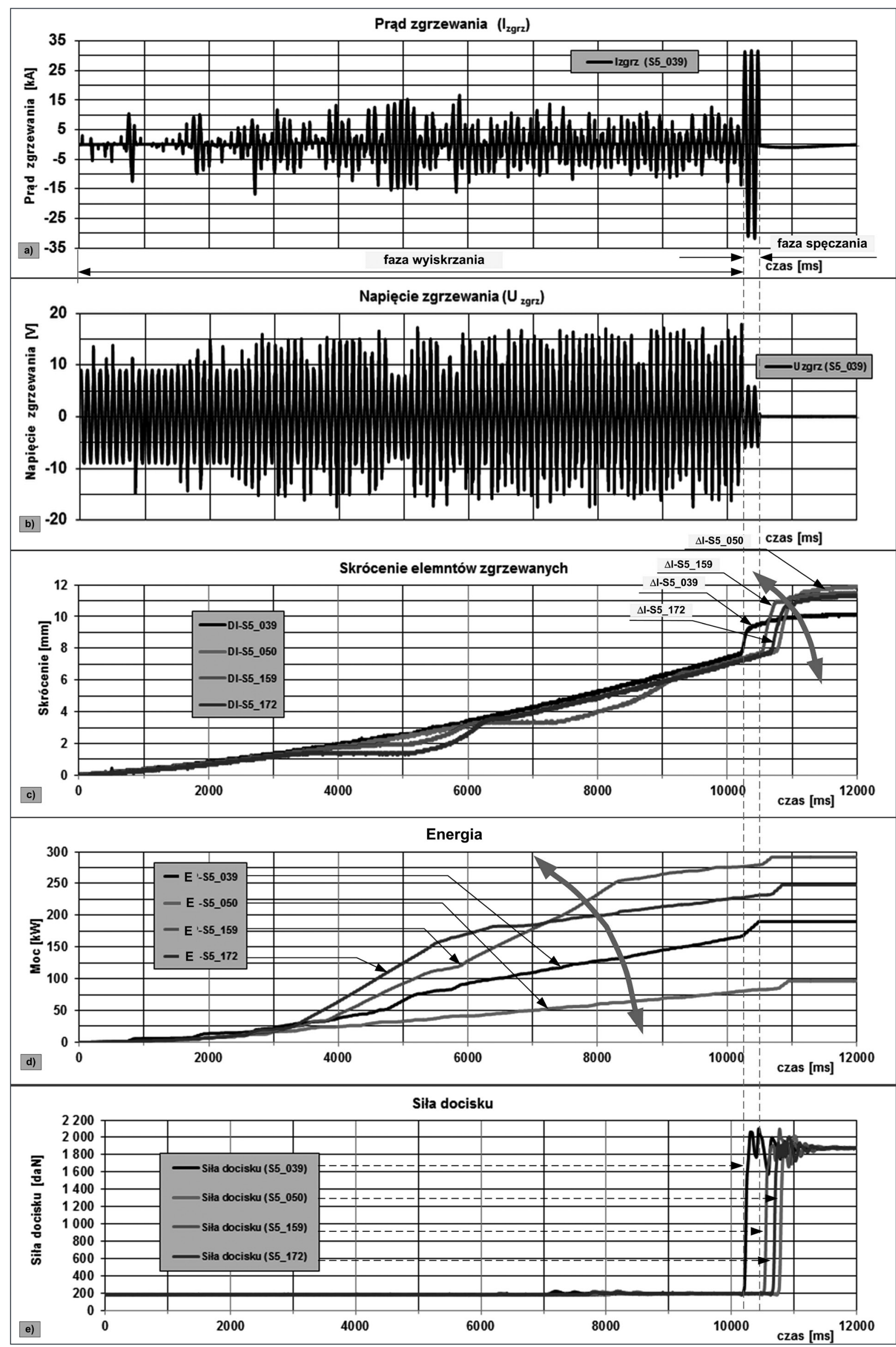

Rys. 7. Przebiegi parametrów charakterystycznych procesu zgrzewania doczołowego iskrowego dla wybranych technologicznych prób zgrzewania (S5_039, S5_050, S5_159, S5_172): a) przebieg prądu zgrzewania, b) przebieg napięcia zgrzewania, c) przebiegi skrócenia elementów, d) przebiegi energii, e) przebiegi siły docisku

Fig. 7. Courses of flash butt welding characteristic parameters for selected technological welding tests): a) welding current waveform, b) welding voltage waveform, c) course of element length reduction, d) course of energy, e) course of force 


\section{Podsumowanie}

System kontroli jakości LogWeld rejestrujący parametry procesu w tym: wartość prądu i napięcia zgrzewania, siły docisku i skrócenia elementów zgrzewanych i dodatkowo przebieg aktualnej energii i rezystancji zastępczej statycznej, w świetle zaprezentowanych wyników spełnia założenia co do skuteczności oceny procesu i kontroli jakości zgrzewania doczołowego iskrowego.

Przeprowadzone badania i analiza rejestrowanych parametrów pozwala na stwierdzenie, że najistotniejsze z punktu widzenia kontroli jakości zgrzewania iskrowego są przebiegi energii dostarczonej do zgrzeiny i skrócenia elementów zgrzewanych (prętów). Różnice w wartości skrócenia są wyraźnie widoczne w fazie spęczania i bezpośrednio po jej zakończeniu (rys. 7). Rozbieżność tych parametrów (energii i skrócenia) są znaczne co pozwala na opracowanie skutecznego algorytmu kontroli procesu.

Rozróżnienie energii w fazie wyiskrzania i fazie spęczania pozwala na zwiększenie skuteczności oceny jakości procesu zgrzewania. Powszechnie utartym poglądem jest to, że większa energia ponad przyjęte wartości nominalne wpływa pozytywnie na jakość połączenia i nie ma wpływu negatywnego. Rejestrowana większa energia w czasie wyiskrzania (rys. 2), generowana jest w styku elektrody z prętem zgrzewanym. Nie jest to energia użyteczna ale energia strat, która jest wydzielana w wyniku częstego zjawiska jakim jest opadanie żużla na elektrody. Efekt w postaci zarejestrowanej większej wartości energii pozwala na wykrycie sytuacji awaryjnej. Sama zaś powiększona wartość energii nie jest energią użyteczną. W efekcie zalegający żużel w styku elektrody z materiałem zgrzewanym ogranicza wydzielanie energii w styku łączonych materiałów.

Kontrola procesu zgrzewania rezystancyjnego, w tym przypadku iskrowego, z pomiarem jedynie prądu bez pomiaru napięcia zgrzewania nie jest wystarczająca. Niezbędny jest pomiar zarówno prądu jak i napięcia zgrzewania dla wyznaczenia dodatkowych wielkości charakterystycznych i pochodnych tych parametrów (rezystancji, mocy, energii), kluczowych z punktu widzenia oceny jakości procesu zgrzewania.

Rozwiązanie w postaci sposobu "Sposób kontroli jakości procesu zgrzewania rezystancyjnego doczołowego iskrowego" zostało zgłoszone do Urzędu Patentowego i otrzymało nr P.410708. [9].

\section{Literatura}

[1] W. Grzechowiak, P. Wróblewski: Zgrzewanie szyn zgrzewarkami dwudrogowymi. IV Ogólnopolska Konferencja Naukowo - Techniczna. „Spawalnictwo dróg szynowych - jakość, niezawodność, bezpieczeństwo", Bochnia 2010.

[2] Klimpel A.: Technologie zgrzewania metali i tworzyw termoplastycznych Wydawnictwo Politechniki Śląskiej Gliwice 1999r.

[3] Poradnik Inżyniera, Spawalnictwo tom 1, 2 WNT Warszawa 2005.

[4] Z. Mikno: Pomiar parametrów elektrycznych procesu zgrzewania rezystancyjnego a jakość połączeń zgrzewanych, Przegląd Spawalnictwa nr 7, 2003, s. 9-16.

[5] Z. Mikno: Inteligentne sterowanie jakością w procesie zgrzewania rezystancyjnego. Biuletyn Instytutu Spawalnictwa nr 6, 2003 s. 46-49.
[6] Z. Mikno, J. Kozaczyński, P. Stodolny: System do kontroli jakości połączeń zgrzewanych z wykorzystaniem sieci neuronowych. Przegląd Spawalnictwa nr 5-7, 2004, s. 6.

[7] Z. Mikno: Wybrane zagadnienia sterowania procesu zgrzewania rezystancyjnego punktowego. Biuletyn IS., nr 2, 2005, s. $39-43$.

[8] Z. Mikno, Kowieski Sz.: Monitorowanie i ocena jakości procesu zgrzewania rezystancyjnego punktowego stali o wysokiej wytrzymałości. Materiały konferencyjne - POSTĘP INNOWACJE i wymagania jakościowe procesów spawania. Międzyzdroje 25-27.05. 2010.

[9] Z. Mikno, A. Pietras, T. Szebeszczyk, K. Czylok: Zgłoszenie patentowe P.470708 pt.: Sposób kontroli jakości procesu zgrzewania rezystancyjnego doczołowego iskrowego" [zgłoszono 2014.12.30]. 